\title{
SATELLITE BASED EDUCATION AND TRAINING IN REMOTE SENSING AND GEO- INFORMATION: AN E-LEARNING APPROACH TO MEET THE GROWING DEMANDS IN INDIA
}

\author{
P.L.N. Raju ${ }^{a} *$ and P. K. Gupta ${ }^{\text {b }}$ \\ ${ }^{a}$ Group Head, Remote Sensing \& Geoinformatics Group, IIRS, Dehradun - 248001, India - raju@iirs.gov.in \\ b Scientist "SC", Geoinformatics Department, IIRS, Dehradun - 248001, India - prasun@iirs.gov.in
}

Commission VI, WG VI/2

KEY WORDS: Remote Sensing, GIS, Training, Web Based, e-learning

\begin{abstract}
:
One of the prime activities of Indian Space Research Organisation's (ISRO) Space Program is providing satellite communication services, viz., television broadcasting, mobile communication, cyclone disaster warning and rescue operations etc. so as to improve their economic conditions, disseminate technical / scientific knowledge to improve the agriculture production and education for rural people of India. ISRO, along with National Aeronautical and Space Administration (NASA) conducted experimental satellite communication project i.e. Satellite Instructional Television Experiment (SITE) using NASA's Advanced Telecommunication Satellite (i.e. ATS 6) with an objective to educate poor people of India via satellite broadcasting in 1975 and 1976, covering more than 2600 villages in six states of India and territories. Over the years India built communication satellites indigenously to meet the communication requirements of India. This has further lead to launch of an exclusive satellite from ISRO for educational purposes i.e. EDUSAT in 2004 through which rich audio-video content is transmitted / received, recreating virtual classes through interactivity.
\end{abstract}

Indian Institute of Remote Sensing (IIRS) established in 1966, a premier institute in south East Asia in disseminating Remote Sensing (RS) and Geographical Information System (GIS), mainly focusing on contact based programs. But expanded the scope with satellite based Distance Learning Programs for Universities, utilizing the dedicated communication satellite i.e. EDUSAT in 2007. IIRS conducted successfully eight Distance Learning Programs in the last five years and training more than 6000 students mainly at postgraduate level from more than 60 universities /Institutions spread across India. IIRS obtained feedback and improved the programs on the continuous basis. Expanded the scope of IIRS outreach program to train user departments tailor made in any of the applications of Remote Sensing and Geoinformation, capacity building for ISRO's operational projects / new satellite missions, developing e-learning contents and launching e-learning courses under twelfth five year (i.e. 2012-17) plan period of Government of India, in addition to continuing of existing distance learning programs for universities.

\section{INTRODUCTION}

\subsection{Background}

Geoinformatics deals with remote sensing and geographic information for natural resource management, infrastructure development, disaster management, facility management and utility services etc. Capacity building of user departments, research organizations and academic institutions is the major task in the field of Geoinformatics. It is also difficult for all of them to leave the job and go for training due to exigencies of the work. In the present context and with the availability of Information and Communication Technology (ICT) many prefer to attend online and live sessions of lectures and practical in elearning mode. It will also help the individual to learn at anytime from anywhere.

Distance education (DE), or distance learning, is a field of education that focuses on the technology and instructional systems design that are effectively incorporated in delivering education to students who are not physically "on site" to receive their education. Instead, teachers and students may communicate asynchronously (at times of their own choosing) by exchanging printed or electronic media, or through technology that allows them to communicate in real time (synchronously). Computers and the Internet have only made distance learning easier, just as it has for many other day-to-day tasks (Phipps R. and Merisotis, J., 1999).

Indira Gandhi Open University National Open University (IGNOU) established in 1985 and is considered to be the largest around the world in terms of intake of over 4 million students spread across 36 countries; through 21 schools of studies and a network of 67 regional centres with around 3000 learner support centres (http://www.ignou.ac.in, 2012). One of the oldest DE universities is the University of South Africa, which has been offering correspondence Education courses since 1946 (established in 1873) with total registered students 347755 (http://www.unisa.ac.za, 2012). The largest DE university in the United Kingdom is the Open University founded 1969 with more than 260000 students (The Open University, UK, 2012). In Germany the Fern University in Hagen was founded 1974. There are now many similar institutions around the world, offer DE with the name Open University (in English or in the local language). There are many private and public, non-profit and for-profit institutions offering courses and degree programs

\footnotetext{
* Corresponding author
} 
through DE (Wikipedia contributors, Distance Education, 2012).

\subsection{Other Distance Learning in India and Worldwide (Gupta et al, 2011)}

Various studies have been done on the availability of distance learning courses in India (Patel D, 2006) and worldwide (Jung, 2005). The courses are either available through public domain networks such as the Internet or private networks such as satellite or wired/wireless local networks. E-learning and Information Communication Technology (ICT) have proved to be a boon for participants of DE. The UN specialised agency for telecommunications ITU states that as of 2009 , the estimated number of Internet users per 100 inhabitants in India is a meagre 5.12, as compared to 39.22, 29.00 and 28.90 of Brazil, Russia and China, respectively (ITU, 2011). This unavailability of high speed internet connections in parts of India has given a definite edge to satellite based educational networks which needs to be exploited. In India, IGNOU and state open universities are the two major bodies imparting $\mathrm{DE}$ at professional level. IGNOU offers a plethora of programs across its 21 schools (IGNOU, 2012). Although the scale at which the programs are conducted is large, standalone organisations can learn important lessons on conducting professional courses as outreach programs. In Indian context, Rajashekhar et al., (2010) points out that satellite communication technology are the "only solution" as the majority $(70 \%)$ of the Indian population lives in inaccessible rural areas along with various economic, cultural, demographical and topographical conditions. Enabling relevant users and institutions to take education to all parts of the country is also one of the goals of the Indian Space Research Organisation (ISRO).

\subsection{Indian Institute of Remote Sensing (IIRS), Indian Space Research Organisation (ISRO)}

The mission of IIRS is "transfer technology through capacity building and research in the field of Remote Sensing and Geoinformatics for sustainable development." It is a leading institute with the primary aim to build capacity in remote sensing and Geoinformatics and their applications through training and education at postgraduate level. It is a constituent unit of the Indian Space Research Organisation (ISRO), Department of Space, Government of India. IIRS was known formerly as the Indian Photo-Interpretation Institute (IPI) and was founded in 1966 with the collaboration of the Government of the Netherlands on the pattern of ITC. IIIRS is the first of its kind in entire south-east Asia. While nurturing its primary endeavour to build capacity among the user community by training mid-career professionals, IIRS has enhanced its capability and evolved many training and education programmes that are tuned to meet the requirements of various target groups, ranging from fresh graduates to policy makers and academics.

IIRS also hosts and conducts training and education programmes offered by the Centre for Space Science and Technology Education in Asia and the Pacific (CSSTEAP), which is affiliated to the United Nations.

The regular capacity building programmes conducted by IIRS are grouped into: 1) Masters degree programmes (M.Tech in RS \& GIS affiliated with Andhra University/ MSc in collaboration with ITC); 2) Postgraduate Diploma programmes; 3) certificate programs; and 4) awareness programmes. In addition to regular programmes special on-demand (tailor-made) courses are conducted for different users, both from India and abroad (Raju et al, 2007). The total capacity of students admitted every year into IIRS regular programs ranges between 300 and 400 . About 8300 students have been trained / graduated so far. To widen the scope of capacity building, IIRS has initiated satellite based distance learning programmes since 2007 and trained about 6323 people through the outreach training mode. It is first of its kind in India and it has become very popular among universities / institutions spread across India.

\subsection{Distance Education in Remote Sensing and Geo- information}

Remote Sensing and Geoinformatics is highly specialized discipline used for assessing, quantification, development and management of resources. Training in this specialized field is essential for its effective utilization. Few universities / Institutions in India started offering Distance Education in Geoinformatics at Masters / Diploma/Certificate course level. Table 1 and 2 provides details of courses offered in India and internationally, respectively.

\begin{tabular}{|c|c|c|c|}
\hline S.No. & Course name & Duration & $\begin{array}{c}\text { Institute } \\
\text { /university }\end{array}$ \\
\hline 1 & $\begin{array}{l}\text { M.Sc. in } \\
\text { Geoinformatics }\end{array}$ & 2 Years & $\begin{array}{l}\text { Indian Institute of } \\
\text { Ecology and } \\
\text { Environment }\end{array}$ \\
\hline 2 & $\begin{array}{l}\text { M.Sc. in } \\
\text { Geoinformatics }\end{array}$ & 2 Years & $\begin{array}{l}\text { Sikkim Manipal } \\
\text { University } \\
\text { Directorate of } \\
\text { Distance } \\
\text { Education }\end{array}$ \\
\hline 3 & $\begin{array}{l}\text { M.Sc. in } \\
\text { Geoinformatics }\end{array}$ & 2 Years & $\begin{array}{l}\text { Annamalai } \\
\text { University } \\
\text { Directorate of } \\
\text { Distance } \\
\text { Education }\end{array}$ \\
\hline 4 & $\begin{array}{l}\text { Postgraduate } \\
\text { Diploma in } \\
\text { Geoinformatics }\end{array}$ & 1 Year & $\begin{array}{l}\text { Uttarakhand Open } \\
\text { university }\end{array}$ \\
\hline 5 & $\begin{array}{l}\text { Certificate course } \\
\text { in Geoinformatics }\end{array}$ & 6 Months & $\begin{array}{l}\text { Uttarakhand Open } \\
\text { university }\end{array}$ \\
\hline 6 & $\begin{array}{l}\text { M.Sc. in } \\
\text { Geoinformatics }\end{array}$ & 2 Years & UNIGIS India \\
\hline 7 & $\begin{array}{l}\text { Professional } \\
\text { Diploma in } \\
\text { Geoinformatics } \\
\end{array}$ & 1 year & UNIGIS India \\
\hline 8 & $\begin{array}{l}\text { Remote Sensing, } \\
\text { GIS and GPS }\end{array}$ & 3 Months & $\begin{array}{l}\text { Indian Institute of } \\
\text { Remote Sensing } \\
\text { (Unique and } \\
\text { satellite based) }\end{array}$ \\
\hline
\end{tabular}

Table 1: Distance Education Programs in India (Raju et al, 2011)

\begin{tabular}{|c|l|c|l|}
\hline $\begin{array}{c}\text { S. } \\
\text { No. }\end{array}$ & \multicolumn{1}{|c|}{ Course } & Duration & \multicolumn{1}{c|}{ University } \\
\hline 1 & $\begin{array}{l}\text { Master of } \\
\text { Geographic } \\
\text { Information } \\
\text { Systems }\end{array}$ & 2+ years & $\begin{array}{l}\text { Penn State } \\
\text { University, World } \\
\text { Campus }\end{array}$ \\
\hline 2 & $\begin{array}{l}\text { Graduate } \\
\text { Certificate in } \\
\text { Geospatial } \\
\text { Intelligence }\end{array}$ & 2+ years & $\begin{array}{l}\text { Penn State } \\
\text { University, World } \\
\text { Campus }\end{array}$ \\
\hline
\end{tabular}




\begin{tabular}{|c|c|c|c|}
\hline 3 & $\begin{array}{l}\text { Postgraduate } \\
\text { Certificate in } \\
\text { Geographic } \\
\text { Information } \\
\text { Systems }\end{array}$ & $1+$ years & $\begin{array}{l}\text { Penn State } \\
\text { University, World } \\
\text { Campus }\end{array}$ \\
\hline 4 & $\begin{array}{l}\text { Master of Science } \\
\text { (Geographic } \\
\text { Information } \\
\text { Science and } \\
\text { Systems) }\end{array}$ & $2+$ years & $\begin{array}{l}\text { UNIGIS } \\
\text { International } \\
\text { Association }\end{array}$ \\
\hline 5 & $\begin{array}{l}\text { Professional } \\
\text { Diploma / } \\
\text { Certificate in GIS }\end{array}$ & $1+$ year & $\begin{array}{l}\text { UNIGIS } \\
\text { International } \\
\text { Association } \\
\end{array}$ \\
\hline 6 & $\begin{array}{l}\text { Various } \\
\text { Certificate } \\
\text { courses }\end{array}$ & $6-9$ weeks & $\begin{array}{l}\text { ITC, The } \\
\text { Netherlands }\end{array}$ \\
\hline 7 & $\begin{array}{l}\text { Master's program } \\
\text { in Geographical } \\
\text { Information } \\
\text { Systems (GIS) }\end{array}$ & 2 years & $\begin{array}{l}\text { Lund University } \\
\text { GIS Centre, Sweden }\end{array}$ \\
\hline 8 & $\begin{array}{l}\text { Certificate/ } \\
\text { Diploma / } \\
\text { Master's degree } \\
\text { in GIS }\end{array}$ & $\begin{array}{l}1 / 2 / 3 \\
\text { years }\end{array}$ & $\begin{array}{l}\text { University of Leeds } \\
\text { \& Southampton, } \\
\text { UK }\end{array}$ \\
\hline 9 & $\begin{array}{l}\text { GIS Certificate } \\
\text { Program }\end{array}$ & 1 year & $\begin{array}{l}\text { Johns Hopkins } \\
\text { University }\end{array}$ \\
\hline 10 & $\begin{array}{l}\text { Online } \\
\text { Undergraduate } \\
\text { GIS Certificate } \\
\text { Course }\end{array}$ & 1 year & $\begin{array}{l}\text { University of West } \\
\text { Florida }\end{array}$ \\
\hline 11 & $\begin{array}{l}\text { Online Graduate } \\
\text { GIS Certificate } \\
\text { Course } \\
\end{array}$ & 1 year & $\begin{array}{l}\text { University of West } \\
\text { Florida }\end{array}$ \\
\hline
\end{tabular}

Table 2: Major Distance Education Programs at International Level (Raju et al, 2011)

There are very good e-learning Masters Programs in Geoinformatics Information System / Geoinformatics programs worldwide, particularly Europe and USA but limited in India and neighboring counties. Starting of Satellite Based Distance Learning Program at IIRS was a good beginning and continued the program because of demand and benefits to the users.

\section{IIRS DISTANCE LEARNING PROGRAM}

The use of Remote Sensing, Geographic Information System (GIS), Global Positioning System (GPS) and associated geospatial technologies is increasing rapidly, thereby demand for more capacity building and institutionalization of the technology. Though the contact based programs are good for individuals to learn and build the capacity but it is not always possible to spare dedicated time due to exigencies of works and also due to financial constraints. So the best option in these circumstances will be distance learning programs

IIRS is utilizing indigenous communication satellites (i.e. EDUSAT \& INSAT 4CR) for conducting live and interactive Distance Learning Program. The training is conducted using $\mathrm{Ku}$ band, National Beam network of CIET-NCERT (Central Institute of Educational Technology - National Council of Educational Research and Training) and CEC-UGC (Consortium for Educational Communication - University Grants Commission).

\subsection{Distance Learning Courses offered from IIRS}

IIRS conducted basic training course on "Remote Sensing, Geographical Information System and Global Positioning System" spread over 3 months for university students. The course dealt the basics in detail supported with simple examples to generate more interest and encourage them to interact more. In addition IIRS has conducted special course in "Advances in Geoinformatics" for short duration in 2011. In addition to regular basic course that is conducted every year during July December, IIRS also offered special course in Hyperspectral Remote Sensing during February - March 2012. Outline of these courses and curriculum of the program as given in Table 3,4 , and 5 .

\begin{tabular}{|c|c|}
\hline $\begin{array}{l}\text { Subject Topics } \\
\text { /Modules }\end{array}$ & Duration \\
\hline \multicolumn{2}{|c|}{$\begin{array}{l}\text { 1. BASIC COURSE ON REMOTE SENSING, GIS \& GPS } \\
\text { (REGULAR, OFFERED ONCE IN A YEAR) }\end{array}$} \\
\hline $\begin{array}{l}\text { Remote Sensing \& } \\
\text { Digital Image } \\
\text { Processing (Module } \\
\text { 1) }\end{array}$ & $\begin{array}{l}2 \text { Weeks - Total } 20 \mathrm{hrs} \mathrm{(} 10 \mathrm{hrs} \text { lectures, } \\
\text { 5hrs interaction /discussion, } 5 \mathrm{hrs} \\
\text { demonstration/ hands on) }\end{array}$ \\
\hline $\begin{array}{l}\text { Global Positioning } \\
\text { System (Module 2) }\end{array}$ & $\begin{array}{l}1 \text { Week - Total } 10 \text { hrs ( } 5 \text { hrs lectures, } \\
2.5 \text { hrs interaction /discussion and } 2.5 \\
\text { hrs demonstration/ hands on) }\end{array}$ \\
\hline $\begin{array}{l}\text { Geographical } \\
\text { Information System } \\
\text { (Module 3) - }\end{array}$ & $\begin{array}{l}2 \text { Weeks - Total } 20 \text { hrs ( } 10 \text { hrs lectures, } \\
5 \text { hrs interaction /discussion, } 5 \text { hrs } \\
\text { demonstration /hands on) }\end{array}$ \\
\hline $\begin{array}{l}\text { Applications and } \\
\text { advances in RS, GIS } \\
\text { and GPS - (Module } \\
\text { 4) }\end{array}$ & $\begin{array}{l}2 \text { Weeks } \\
\text { Total } 16 \text { hrs (12 hrs lectures, } 4 \mathrm{hrs} \\
\text { interaction /discussion, ) }\end{array}$ \\
\hline
\end{tabular}

Note: Open source image analysis \& geospatial tools were used as part of practical demonstrations with the help of OSGEOIndia.

Table 3: Course Structure and syllabus of Basic Course on Remote Sensing, GIS \& GPS

\begin{tabular}{|c|c|}
\hline Subject Topics /Modules & Duration \\
\hline $\begin{array}{l}\text { 2. SPCECIAL COURSE IN ADVANCES OF } \\
\text { GEOINFORMATICS }\end{array}$ & \\
\hline $\begin{array}{l}\text { Indian Space Program- Present \& Future, } \\
\text { Earth Observation \& Geoinformatics } \\
\text { Technological Trends, Spatial Databases, } \\
\text { Geo Data Modelling, Programming \& GIS } \\
\text { Customization, Web GIS, Mobile Mapping, } \\
\text { 3D GIS \& Visualisation, Tele Matics \& } \\
\text { Transportation Systems. Spatial Decision } \\
\text { Support System, Open Source GIS(OSGEO } \\
\text { Live Demonstration) }\end{array}$ & $\begin{array}{l}4 \text { weeks - Total } \\
18 \mathrm{hrs} \mathrm{(12} \mathrm{hrs} \\
\text { lectures, 6hrs } \\
\text { interaction } \\
\text { /demonstration } \\
\text { ) }\end{array}$ \\
\hline
\end{tabular}

Table 4: Course Structure and syllabus of special course in Advances of Geoinformatics

\begin{tabular}{|c|c|}
\hline Subject Topics /Modules & Duration \\
\hline \multicolumn{2}{|c|}{$\begin{array}{l}\text { 3. SPECIAL COURSE IN HYPERSPECTRAL REMOTE } \\
\text { SENSING }\end{array}$} \\
\hline $\begin{array}{l}\text { Basic understanding, spectroscopy, spectral } \\
\text { libraries, HSR preprocessing, IR sounding and } \\
\text { retrieval of atmospheric parameters, HRS data } \\
\text { processing ( data reduction, information } \\
\text { extraction and end member selection), image } \\
\text { classification and application studies for }\end{array}$ & $\begin{array}{l}7 \text { weeks } \\
\text { Total } 30 \mathrm{hrs} \\
(14 \quad \mathrm{hrs} \\
\text { lectures, } 7 \mathrm{hrs} \\
\text { interaction } \\
\text { and } 9 \text { hours }\end{array}$ \\
\hline
\end{tabular}


minerals, water quality, planetary exploration, of s/w / HRS snow, ice, glaciers, crops, soils and forestry . $\quad$ instruments demo

Table 5: Course Structure and syllabus of special course in Hyperspectral Remote Sensing

\subsection{Approach of IIRS Outreach Program}

The distance learning program involves lectures / practical / software demonstrations telecasted live from IIRS teaching studio for one and half hour to two hour session on a specified time and date as per the announcement in advance to all the participating institutions. Daily programs are flashed in bulletin boards on daily basis at IIRS website. Presentation material and reading material are made available to all registered participants through dropbox before commencement of live program. Presently IIRS is using "TrainNet" based Learning Management System instead of VLC based streaming, helping quality transmission. The LMS software has many modules namely Course Builder, Push FTP, Teaching end and recorder personal computer (PC) modules. The course builder module converts the Microsoft Power Point Presentation into web based HTML format. Push FTP allows this HTML file and other materials to be transported over to multiple student ends in real time. Teaching PC has many capabilities such as chat, email, highlighter, video calling and slide navigation etc. Recorder PC allows the student ends to view and record the sessions.

\subsection{Throughput of IIRS Outreach Programs}

IIRS has utilized EDUSAT satellite for conducting 4 such training programs during 2007 till 2009 and INSAT 4CR for conducting the next 4 programs. Till March 2012, more than sixty universities participated with the turnover of students 6323 students benefited IIRS distance learning program (Table 6). The map showing IIRS network of classrooms benefitted from outreach program is shown in Figure 1.

\begin{tabular}{|c|c|c|c|c|c|c|c|c|c|}
\hline \multicolumn{10}{|c|}{ IIRS Outreach Program Summary } \\
\hline & 1 & 2 & 3 & 4 & 5 & 6 & 7 & 8 & Total \\
\hline $\begin{array}{l}\text { No. of } \\
\text { Lecture Hrs. }\end{array}$ & 45 & 34 & 36 & 35 & 41 & 10 & 48 & 20 & 249 \\
\hline $\begin{array}{l}\text { Hrs. of } \\
\text { Interactive } \\
\text { Session }\end{array}$ & 15 & 17 & 18 & 12 & 10 & 3 & 24 & 10 & 99 \\
\hline Total Hrs & 60 & 51 & 54 & 47 & 51 & 13 & 72 & 30 & 349 \\
\hline $\begin{array}{l}\text { Total No. of } \\
\text { Participants }\end{array}$ & 349 & 931 & 915 & 931 & 982 & 179 & 1383 & 653 & 6323 \\
\hline $\begin{array}{l}\text { Total } \\
\text { Universities } \\
\text { Participated }\end{array}$ & 12 & 22 & 40 & 48 & 26 & 10 & 36 & 19 & 64 \\
\hline $\begin{array}{l}\text { Year of the } \\
\text { course }\end{array}$ & 7 & 7 & 8 & 9 & 10 & 11 & 11 & 12 & \\
\hline
\end{tabular}

Table 6: IIRS Outreach Program Summary

\section{FEEDBACK}

Feedback is very important component of distance learning programs and IIRS has adopted very good feedback mechanism by contacting the individual students and university coordinators online after completion of the courses. Regular workshops are conducted after the completion of the courses by inviting the university coordinators and student representatives from all the participating universities. Feedbacks have been taken to address the issues on course structure, duration etc. and plan for improvement in future programs and wider participation. Majority of the participants expressed satisfaction and provided positive feedback and willing to participate in the future programs (Gupta et al, 2011).

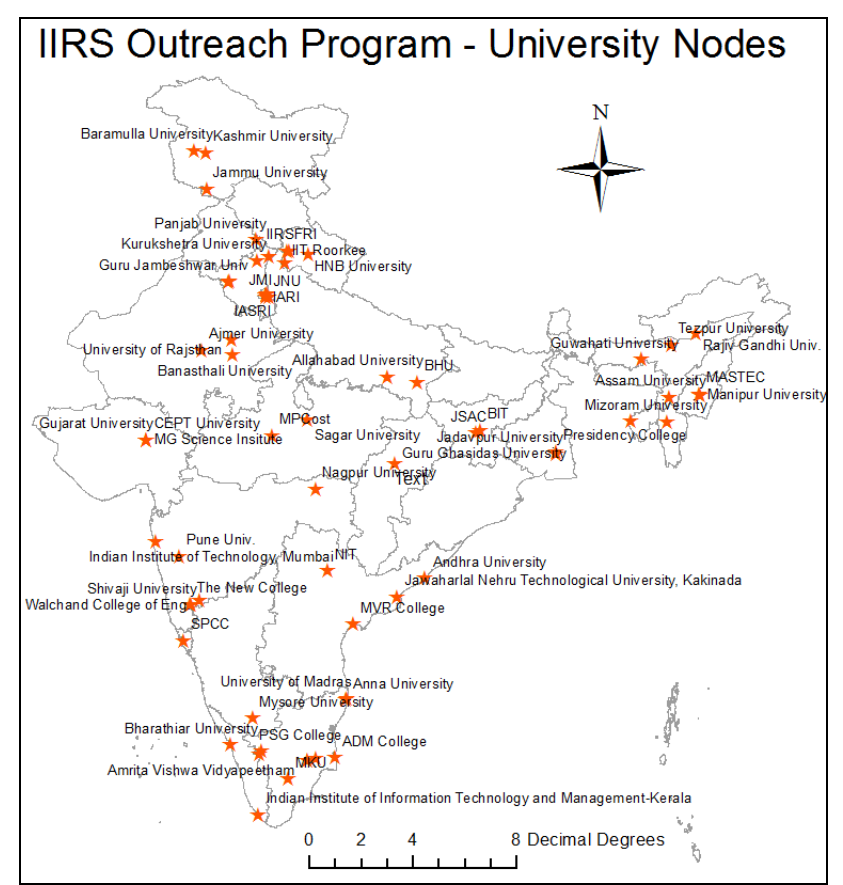

Figure 1: IIRS Network of outreach program classrooms

\section{CONCLUSION AND FUTURE PLANS}

\subsection{Conclusions}

Satellite Interactive Terminals (SITs) are established spread across India at Universities under CEC-UGC setup, Technical institutions under AICTE and State Science and Technology Centres as part of Vigyan Prasar set up. All these infrastructure facilities are utilized for live and interactive Distance Learning Programs benefitting the students to learn remote sensing and geoinformation studying at undergraduate level (final year only) and postgraduate level. There is no issue of internet bandwidth constraints as it is done through satellite communication network.

In addition, some individuals who are not part of the satellite communication network but wanted to learn in e-learning mode. Additional feed is provided to stream the same courses through internet using A-View streaming, benefitting the individuals to learn and benefit from the IIRS distance learning programs.

The response to IIRS outreach program is overwhelming and the demand is increasing over the years.

The major limitation of distance classes/ e-learning are hands on with ground truth and field equipments, hands on experience of software tools, interaction and group discussions. Some of the bottle necks can be sorted with recent developments with virtual learning methods in simulated environment and easy learning tutorials. Discussion boards will also help to some extent in enhancing the learning.

\subsection{Future Plans}

Capacity Building in RS and GIS plays important role for planning, development initiatives for different sectors like natural resources, infrastructure and utility services. The vast country like India where there are large number of line departments and the demand for training these user departments is quite large and meeting their capacity building using contact 
based programs will be next to impossible. Satellite based communication is a boon which can facilitate e-learning with rich video/audio content and data transfer, considering the bandwidth constraints in internet environment. Realizing the need, the institute expanded the outreach program under 12th Five Year plan with the following objectives:

- Extend the teaching to remote areas (including rural areas) classrooms / user centre's by satellite communication linkages for receiving the RS and GIS training.

- Capacity Building in the areas of Indian Space Research Organisation's natural resource operational activity, meeting the present user demands at Central /State Level.

- ISRO's future satellite missions and technology transfer in newer areas using the satellite based learning methods.

- Establishment of mobile / portable transmit/receiving satellite networks at the user department level for providing the tailor-made / specialized training programs.

- Continue with successful Distance Learning Program on "Basics of Remote Sensing, GIS and GPS" for postgraduate students of Indian universities, conducted since 2007. Table 6 provides the summary of satellite based Distance Learning Programs conducted at IIRS since 2007

- Development of web based e-learning content with appropriate screen casting (videos/audio), animations, blogs, wikis, and discussion boards for synchronous /asynchronous learning.

- Organizing user interaction meetings / workshops in virtual environment, saving on travel and other expenditure.

The expected outcome of this impressive program is to enable large number of short duration theme specific training programs for user Departments thereby reducing the cost and movement of officials, building the rich e-learning content in RS and GIS and thereby expanded capacity building activity, frequent interaction with users and continuing with more university participation in IIRS distance learning outreach program.

\section{REFERENCES}

Gupta P.K., Raju PLN, Roy PS. 2011. User Response Analysis of IIRS Geomatics EDUSat Distance Learning Program and $\begin{array}{lllll}\text { Future Challenges. Proceedings of ISPRS } & W G & V I / 4\end{array}$ International Workshop on "Multinational Geomatics Capacity Building - Achievements and Challenges”, IIRS, April 7-8, 2011.

IGNOU, 2011. Data from IGNOU Website Accessed on June 18, 2011 <http://www.ignou.ac.in/ignou/aboutignou>

ITU, 2011. WTI Information Technology Public Report Year 2009. http://www.itu.int/ITU-D/ICTEYE/Reports.aspx (accessed on March 26, 2011)

Jung I., 2005. Quality Assurance Survey of Mega Universities. In C. McIntosh (Ed.), Perspectives in Distance Education
Lifelong Learning and Distance Higher Education. Canada: Commonwealth of Learning, pp. 79-95.

Patel, D., 2006, E-learning and its Impact on LIS profession. Conference on ICT for Facilitating Digital Learning Environments. Bangalore, paper $-\mathrm{X}$.

Phipps, Ronald; Merisotis, Jamie., 1999. What's the difference? A review of contemporary research on the effectiveness of distance learning in higher education. Institution for Higher Education Policy, WashingtonDC, http://www.eric.ed.gov/ERICDocs/data/ericdocssql/content_stor age_01/0000019b/80/17/87/09.pdf (accessed 22 Mar. 2008).

P.L.N. Raju, V.K. Dadhwal and C. Jeganathan, 2007, "GIS Education and Training at Indian Institute of Remote Sensing", GIS Development Asia Pacific, Mach 2007, Vol 11, Issue 3.

P.L.N. Raju, P.S. Roy and Prasun K. Gupta, 2011, "Satellite Based Live and Interactive Distance Learning Program in the field of Geoinformatics - A Perspective of Indian Institute Of Remote Sensing, India", ISPRS WG VI/1,2 Workshop ELearning 2011 within ACRS. 4-6 October 2011, Taipei, Taiwan

Rajashekhar S.L., Ayyangar G.V. and Sharma R, 2010, Satellite-based Distance Education in Digital Paradigm: ISRO perspective. 6th International Conference on Digital Content Multimedia Technology and its Applications (IDC) IEEE, pp. 366-371.

V.K. Dadhwal and P.L.N. Raju, 2007. Four decades of capacity building in applications of space-based earth observation and Geoinformatics at Indian Institute of Remote Sensing, Proceedings of 58th International Astronautical Congress, organised at NRSA, Hyderabad during Sept. 24-28, 2007. IAC07-E1.I.08.

Wikipedia contributors, 2008. Distance education, Wikipedia, The Free Encyclopaedia. http://en.wikipedia.org/w/index.php?title=Distance_education\& oldid-197963792 (accessed 22 Mar 2008).

\section{ACKNOWLEDGMENT}

IIRS Outreach Program is funded by National Natural Resource Management System (NNRMS) under Standing committee on Education and Training (SC-T), ISRO. The authors are thankful to Chairman ISRO, ISRO-SCPO, DECU and Director IIRS for their advice, technical suggestions and helping in day-to-day implementation of the program. 